\title{
Proteasome Activator Complex Subunit 3
}

National Cancer Institute

\section{Source}

National Cancer Institute. Proteasome Activator Complex Subunit 3. NCI Thesaurus.

Code C95864.

Proteasome activator complex subunit 3 (254 aa, $~ 30 \mathrm{kDa}$ ) is encoded by the human PSME3 gene. This protein is involved in the regulation of proteasome activity, cell cycle progression and apoptosis. 